Globalization and Cyberculture 
Kehbuma Langmia

\section{Globalization \\ and Cyberculture}

An Afrocentric Perspective 
Kehbuma Langmia

Department of Strategic,

Legal and Management Communication

Howard University

Washington, District of Columbia, USA

ISBN 978-3-319-47583-7

DOI $10.1007 / 978-3-319-47584-4$

ISBN 978-3-319-47584-4 (eBook)

Library of Congress Control Number: 2016957409

(C) The Editor(s) (if applicable) and The Author(s) 2016

This book was advertised with a copyright holder in the name of the publisher in error, whereas the author holds the copyright.

This work is subject to copyright. All rights are solely and exclusively licensed by the Publisher, whether the whole or part of the material is concerned, specifically the rights of translation, reprinting, reuse of illustrations, recitation, broadcasting, reproduction on microfilms or in any other physical way, and transmission or information storage and retrieval, electronic adaptation, computer software, or by similar or dissimilar methodology now known or hereafter developed.

The use of general descriptive names, registered names, trademarks, service marks, etc. in this publication does not imply, even in the absence of a specific statement, that such names are exempt from the relevant protective laws and regulations and therefore free for general use. The publisher, the authors and the editors are safe to assume that the advice and information in this book are believed to be true and accurate at the date of publication. Neither the publisher nor the authors or the editors give a warranty, express or implied, with respect to the material contained herein or for any errors or omissions that may have been made.

Cover illustration: Abstract Bricks and Shadows (C) Stephen Bonk/Fotolia.co.uk

Printed on acid-free paper

This Palgrave Macmillan imprint is published by Springer Nature The registered company is Springer International Publishing AG

The registered company address is: Gewerbestrasse 11, 6330 Cham, Switzerland 
This book is dedicated to my Mom and Dad for their unconditional love 


\section{FOREWORD}

It is an honor to have been asked to write the foreword to this impressive book that has been written by one of the rising figures in social media communication. Kehbuma Langmia, Professor and Chair of the Department of Strategic, Legal and Management Communication at Howard University's School of Communications, is an African-born scholar with a global experience of having studied and worked in Africa, Europe, and North America. This new publication of his brings a sigh of relief to scholars and students of cyberculture communication and globalization who have been yearning for an Afrocentric perspective on the burgeoning subject.

Undeniably, the World Wide Web has revolutionized communication in a way never envisaged by even communication experts a few decades ago. Cyberculture communication, in particular, has framed and given new character to human-to-human communication where humanity's hitherto close-knit interpersonal rapports are being replaced by voice, numbers, and letters. If this comes with a profound effect on cultures, it definitely comes with more profound effects on cultures in oriental settings where people have to face the challenges of employing the new communication paraphernalia in languages that are often foreign to them. Tropical Africa is an excellent example of a setting grappling with this new communication dispensation, and this book focuses on the challenges faced by users in this part of the world as well as the effects of cyberculture in this often forgotten continent. The author begins by tracing a long-standing communal way of life of African peoples and 
their mode of communication. What caught my attention in this regard is the author's aversion that

The small people in South Eastern Cameroon (Joiris 1996) and the Bushmen and Hottentots in South Africa still practiced their old communicative methods to get to other human creatures. Drums, gongs, vuvuzelas and other man-made tools of communications were still being used in kingdoms and chiefdoms in West Africa especially among the non-western educated citizens

The notion of social communication practice in Africa predates the colonial experience. The background material of communication in precolonial Africa derived from the cultural, social, political, and historical happenings in people's lives in often dramatic fashion. One of the peculiar characteristics of this mode was that they were always communal. There was hardly a clear distinction between interlocutors. Those festivals held around planting and harvesting or before and after wars were commonplace communal activities. Jomo Kenyatta's portrayal of the Ituika ceremony among the Agikuyu of Kenya in Facing Mount Kenya (1965) is a detailed articulation of a communal performance in precolonial Africa. The duration of Ituika spanned several months during which everybody in the community would participate at the scheduled events. Here, even performances marking transitions of any type in the lives of individuals, like the rites of passage from childhood to adulthood and marriage or initiation into any of the vital societies in the community, were communal. Reducing these ceremonies into private occasions would be impossible in a setting where the individual was pretty much an expression of the community in the same manner that the community was an expression of its constituent individuals. This strong sense of interdependence between the individual and the community translates into constant exchanges between the actors, those performing at the center of the playground, and the audience; those acting at the center were by design an extension of those watching and vice versa. At any point in time, those watching or listening could suddenly be the ones being watched or listened to. In the same vein, those acting could at any stage of the performance be the ones watching. This age-old interactive communication model would be challenged by colonial establishments during the colonial period. The struggle over performances was essentially over who was in control of the form and 
the social relevance to which the form was put. It was primarily the struggle over form to control content as the colonial establishment sought to be in control to demonstrate power while the anticolonial institutions yearned for the same control to implement their revolutionary agenda against colonization. This thorny binary relation continues with the postcolonial dispensation where the governments of African countries are in firm control of the media.

The long-standing control over the media by respective establishments in the continent faced an epic challenge in the action of a culminating figure and Egyptian social media activist, Wael Ghonim. Ghonim is the architect of the 2011 Facebook/Twitter revolution in Egypt, a continuation of a string of revolutionary movements that would result in what is commonly referred to as the Arab Spring. Arab Spring saw the ousting of age-old dictators in Tunisia, Egypt, Libya, and Burkina Faso from power. Social media provided spaces hitherto marginalized and subdued people saw as theirs.

This novel text can be used as a stand-alone exploration of the impact of the state of communication revolution in tropical Africa. It is an excellent supplement to numerous text books on the subject that pay cursory attention to the communication revolution on tropical Africa or does not explore the continent at all. The wealth of knowledge to be tapped from this book is vindicative of the age-old African proverb that "until the lions have their own historian, the history of the hunt will only glorify the hunter."

Department of English and Foreign Languages Delaware State University, USA
Victor N. Gomia Associate Professor 


\section{ACKNOWLEDGMENTS}

I wish to thank my Heavenly gifts: Irmagard Nambu Langmia, Brandon Kehbuma Langmia and Gabriel-Phil, Anchang Langmia. You are the reason I get up and look up to the sky every day. 


\section{Contents}

1 Introduction 1

2 Traditional African and Western Modern Cultures 5

3 Cyberculture, Cybersubculture, and Africa 21

4 Road to Cyberculture in Tropical Africa 33

5 Requiem for In-Person Verbal/Nonverbal Communication

6 New Media New Cultural Dependence 57

7 Cyberculture and the Digital Divide 73

8 Cyberculture and Identity 83

9 Cybernetic Psycho-Syndrome 97

10 Cybersecurity, Cyberculture, and Africa 107

11 Cyberculture and E-health Communication in Africa 115 
xiv CONTENTS

12 Conclusion 121

$\begin{array}{ll}\text { References } & 125\end{array}$

$\begin{array}{ll}\text { Index } & 135\end{array}$ 


\section{List of AbBreviations}

$\begin{array}{ll}\text { AM } & \text { Amplitude modulation } \\ \text { AOL } & \text { American Online Line } \\ \text { APPs } & \text { Applications } \\ \text { AU } & \text { African Union } \\ \text { BBC } & \text { British Broadcasting Corporation } \\ \text { CNN } & \text { Cable Network News } \\ \text { DARPA } & \text { Defense Advanced Research Project Agency } \\ \text { DoD } & \text { Department of Defense } \\ \text { ECT } & \text { Electronic Communication Theory } \\ \text { EHR } & \text { Electronic health records } \\ \text { FM } & \text { Frequency modulation } \\ \text { FtF } & \text { Face-to-face } \\ \text { GNP } & \text { Gross national product } \\ \text { ICT } & \text { Information communication technology } \\ \text { ITU } & \text { International Telecommunication Union } \\ \text { LBGT } & \text { Lesbian bisexual gay transgender } \\ \text { MSN } & \text { Microsoft Network } \\ \text { MTV } & \text { Music Television } \\ \text { NATO } & \text { North Atlantic Treaty Organization } \\ \text { NGO } & \text { Nongovernmental organization } \\ \text { NSA } & \text { National Security Administration } \\ \text { NWICO } & \text { New World Information and Communication Order } \\ \text { OAU } & \text { Organization of African Union } \\ \text { PC } & \text { Personal computer } \\ \text { SACSAW } & \text { South African Cybersecurity Awareness Workshop } \\ \text { SAP } & \text { Structural Adjustment Program } \\ \text { SW } & \text { Short wave } \\ & \end{array}$

